\title{
Effectiveness of best management practices in improving water quality in a pasture-dominated watershed
}

\author{
I. Chaubey, L. Chiang, M.W. Gitau, and S. Mohamed
}

\begin{abstract}
The nonpoint source pollution problem can be controlled by implementing various best management practices (BMPs) in the watershed. However, before such practices are adopted, their effectiveness at various spatial and temporal scales must be evaluated. The objective of this research was to evaluate a suite of BMPs in a pasture-dominated watershed in their effectiveness at controlling nutrient losses. A total of 171 different BMP combinations incorporating grazing and pasture management, riparian and buffer zones, and poultry litter applications were evaluated for their effectiveness using the Soil and Water Assessment Tool (SWAT) model.The SWAT model was parameterized using detailed farm and watershed-scale data. The stochasticity in weather was captured by generating 250 various possible weather realizations for a 25-year period, using measured historical climate data for the watershed. Model results indicated that losses of both total nitrogen, mineral phosphorus, and total phosphorus increased with an increase in litter application rates. For the same application rates, greatest losses were predicted for fall application timings compared to spring and summer applications. Overgrazing resulted in greater nutrient losses compared to baseline conditions for all application rates, timings, and litter characteristics, indicating that overgrazing of pasture areas must be avoided if any improvement in the water quality is to be expected.Variability in weather conditions significantly affected BMP performance; under certain weather conditions, an increase in pollutant losses can be greater than reductions due to BMPs implemented in the watershed. Buffer strips and grazing management were two most important BMPs affecting the losses of total nitrogen and total phosphorus from the pasture areas.
\end{abstract}

Key words: best management practices (BMP)—BMP effectiveness-Conservation Effects Assessment Project (CEAP)—nonpoint source (NPS) pollution-pasture watershed-Soil and Water Assessment Tool (SWAT) model—weather uncertainties

The impact of agricultural practices on water quality has received considerable attention during the last two decades, with a number of studies indicating agricultural chemicals to be one of the main sources of nonpoint source pollution (NPS) (Gilley and Risse 2000; Harmel et al. 2004; Yu et al. 2004). Intensive agricultural practices are identified to release significant amounts of nutrients, especially nitrogen $(\mathrm{N})$ and phosphorus $(\mathrm{P})$, fecal bacteria, and sediment to receiving water bodies (Gillingham and Thorrold 2000; Monaghan et al. 2005). For example, excess application of animal manure and inorganic fertilizers has been shown to increase nitrate nitro- source, retarding pollutant transport, or treating the impacted water bodies. Management practices can be structural (e.g., buffer zone, waste treatment lagoons, wetlands, grassed waterways, etc.) or nonstructural (e.g., nutrient management, grazing management, etc.) and are commonly used in combinations based on site-specific constraints to achieve the overall agricultural production and water quality improvement goals (USEPA 2003). Even though various BMPs have been shown to reduce losses of NPS pollutants and improve water quality at the scale of implementation, i.e., field/farm scales, their effectiveness in improving water quality at watershed scale is not clear. Some BMPs may be effective in controlling one pollutant while, at the same time, may adversely affect the losses of other pollutants (Gitau et al.2005; Merriman et al. 2009).Very little information is currently available demonstrating if a suite of BMPs, when implemented simultaneously, work synergistically or whether some BMPs cancel the NPS pollution reduction benefits of others.

The success of NPS control is affected by the degree of hydrologic relationships between nonpoint source, receiving water, biogeochemical processes, and other factors (e.g., weather, watershed geomorphologic characteristics, choice of BMPs, placement and maintenance of BMPs) (Chambers et al. 2006). Often, watershed models are used to evaluate BMP performance in reducing nonpoint source pollution from agricultural watersheds and for making watershed management recommendations. The watershed models can be used to make watershed response predictions in two modes based on the time scale of interest: hindcast: to retrospectively evaluate how much water quality would have been improved if certain suites of BMPs were implemented; and futurecast: to evaluate various watershed management options based on current conditions to develop watershed management plans. One

Indrajeet Chaubey is an associate professor, and Lichi Chiang is a graduate research assistant in the Department of Agricultural and Biological Engineering, Purdue University, West Lafayette, Indiana. Margaret W. Gitau is an assistant professor in the Department of Biological and Agricultural Systems Engineering at Florida A\&M University, Tallahassee, Florida. Sayeed Mohamed is a research associate at the Computing Research Institute, Rosen Center for Advanced Computing, Purdue University, Indiana. 
of the limitations of the model applications in a futurecast mode is that certain assumptions about the future weather conditions are required. Many studies have indicated that water quality can be affected by weather. For example, increasing temperature in winter was related to increasing sediment and nutrient losses due to greater runoff (Bouraoui et al. 2004), and precipitation was shown to affect the nutrient losses (Chambers et al. 2006). Considering uncertainty in future weather conditions can help set realistic expectations for BMP performance in improving water quality (SWCS 2006; Garbretch et al. 2006; Garbretch 2008).

The objectives of this research were to (1) evaluate the effectiveness of various structural and nonstructural BMPs in improving water quality at the watershed scale, (2) quantify interactions among BMPs in reducing pollutants of concern, and (3) evaluate impacts of uncertainty in weather conditions on water quality improvement in a pasture-dominated watershed. This study is a part of the Conservation Effects Assessment Project (CEAP) to evaluate watershed-scale performance of agricultural BMPs at improving water quality. A total of 171 BMP scenarios consisting of three different grazing management options (no grazing, optimum grazing, and overgrazing), three dif-

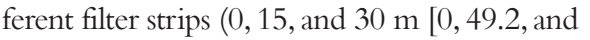
$98.4 \mathrm{ft}]$ ) and 19 different nutrient management options were evaluated.

\section{Materials and Methods}

Study Area. This study was conducted in the Lincoln Lake CEAP watershed, a 32 $\mathrm{km}^{2}(7,907 \mathrm{ac})$ agricultural watershed within the Illinois River Basin located in northwest Arkansas and eastern Oklahoma (figure 1). To improve the water quality in the Illinois River, the Oklahoma Water Resources Board has implemented a total phosphorus concentration limit of $0.037 \mathrm{mg} \mathrm{L}^{-1}$ at the Oklahoma/Arkansas state boundary (OWRB 2010). The measured total phosphorus (TP) concentration at the Illinois River near the Arkansas-Oklahoma border was about 0.4 $\mathrm{mg} \mathrm{L}^{-1}$ (Green and Haggard 2001).

Moores Creek and Beatty Branch are the two major tributaries in the Lincoln Lake watershed, representing 21 and $11 \mathrm{~km}^{2}(5,189$ and $2,718 \mathrm{ac}$ ) of the watershed area, respectively. The watershed has a mixed land use with pasture, forest, urban residential, urban commercial, and water representing 35.8\%, $48.6 \%, 11.9 \%, 1.5 \%$, and $2.2 \%$ of the water-

\section{Figure 1}

Location of Beatty Branch, Moores Creek, land-use distribution and the gauging stations in the Lincoln Lake watershed.

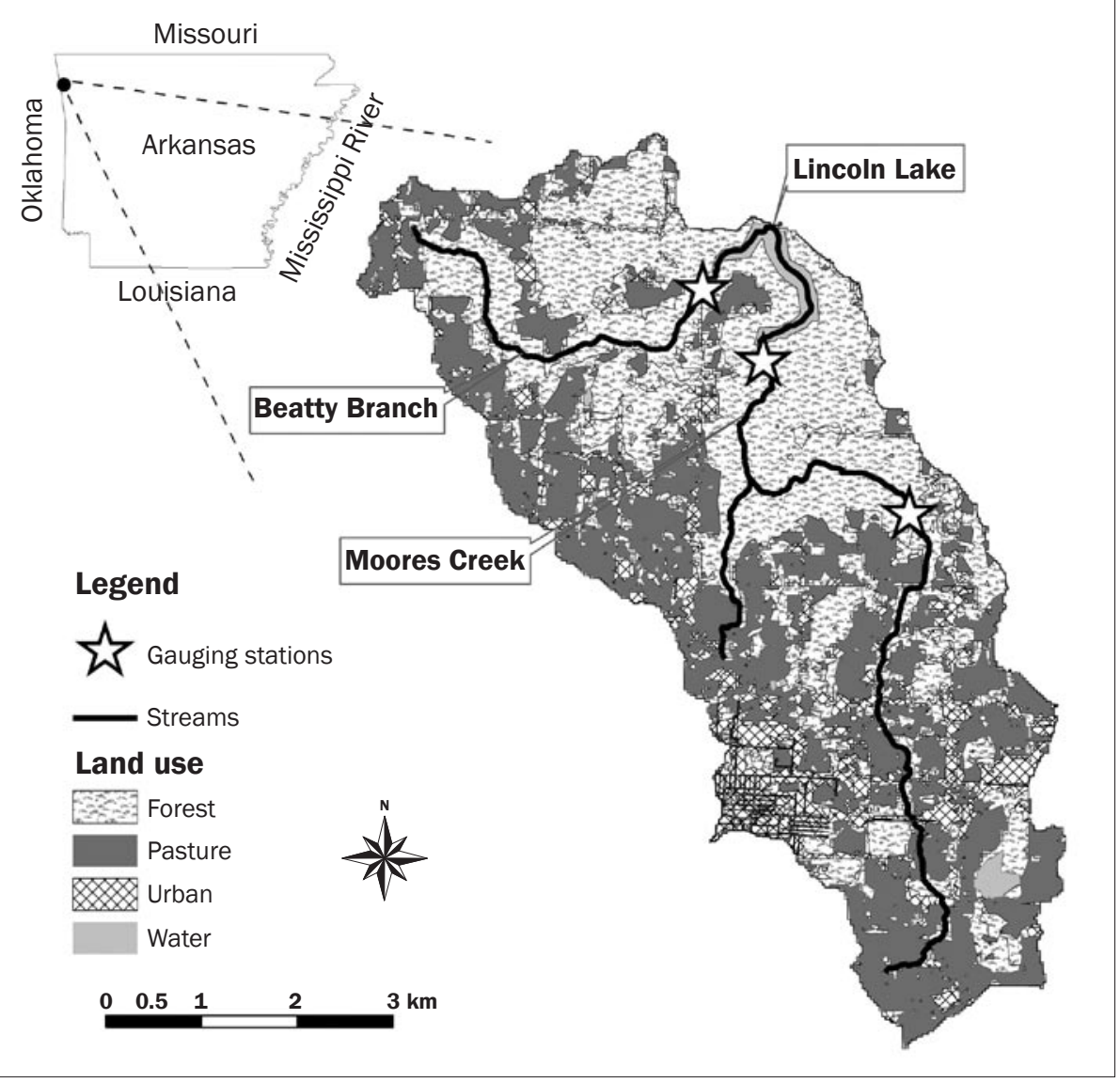

shed area, respectively (figure 1). The pasture land-use area has decreased from $43 \%$ to $36 \%$, primarily due to increasing urbanization in the watershed since 1994 (Gitau et al. 2010). Pasture fields in the watershed have numerous poultry, beef, and dairy cattle production facilities. Excessive litter and manure application for perennial forage grass production in the watershed have been shown to increase surface and groundwater pollution due to increasing losses of sediment, nutrients, and pathogens (Edwards et al. 1996). Since 1994, BMPs implemented in the watershed have increased from $1 \%$ to $34 \%$ of the watershed area, representing $53 \%$ of total pasture areas in the watershed in 2004.

Flow and water quality monitoring have been performed at various sites in the watershed since 1991, funded by the Arkansas Soil and Water Conservation Commission (now Arkansas Natural Resources Commission) and the US Environmental Protection Agency (USEPA) through various projects in the watershed. Location of stream flow and water quality monitoring along with the time frame for various data collected in the watershed are described by Gitau et al. (2010). At all the sites, stream flow was monitored continuously using a pressure transducer to measure flow depth and depth-discharge relationships at each site. Water quality data for sediment, $\mathrm{N}$, and $\mathrm{P}$ were collected separately during storm and base flow conditions. Flow-weighted composite samples were collected during each storm event using an autosampler. Water quality during base flow conditions was quantified by collecting grab samples every two weeks. All water samples were analyzed using standard methods of analyses. Details of flow and water quality monitoring are provided by Vendrell et al. (1997; 2001) and Nelson et al. (n.d.).

Soil and Water Assessment Tool Model Description and Input Data Preparation. The Soil and Water Assessment Tool (SWAT) model was used to evaluate the impacts of various BMPs on water quality improvement in the watershed. The model can predict long-term impacts of land management on water, sediment, and agricultural chemi- 
cal yields at different scales in a complex watershed (Arnold et al. 1998). The major components of the SWAT model are climate, hydrologic cycle, sediment, nutrients, pesticide, bacteria, plants, and management. The SWAT model has been widely used to quantify the water quality impacts of various management decisions at various spatial scales, ranging from field and farm level (Gitau et al. 2008; Gollamudi et al. 2007; Maski et al. 2008; Srivastava et al. 2007) to large watersheds (Green et al. 2006; Quansah et al. 2008; White and Chaubey 2005) and at various temporal scales, ranging from daily to several decades (Heathman et al. 2009; Renschler and Lee 2005). More than 250 peer-reviewed journal articles have been published demonstrating the SWAT applications on sensitivity analyses, model calibration, hydrologic analyses, pollutant load assessment, and climate change impacts on hydrology and pollutant losses (Gassman et al. 2007). The SWAT model is currently being applied in many of the USDA CEAP watersheds to evaluate the watershed response under various BMP implementation conditions (Harmel et al. 2008; Heathman et al. 2008).

The major geographic information system input files for the SWAT model were the digital elevation model at $30 \mathrm{~m}$ (98.4 ft) resolution (USGS 2004), land use and land cover at $28.5 \mathrm{~m}(93.5 \mathrm{ft})$ resolution (CAST 2004), and SSURGO soil data. Based on the digital elevation model and specification of streams and inlet/outlet, the SWAT ArcView Interface was used to delineate the watershed into 72 subbasins. Based on the land use and soil data, the watershed was partitioned into homogeneous units (hydrologic response units [HRUs]) by setting threshold percentages of dominant land use and soil type (Neitsch et al. 2002). We had detailed farm/ field management data for the watershed, including litter and nutrient management, grazing management, and locations of BMPs since 1992. In order to capture this detailed information in the SWAT model parameterization, HRUs were defined using a $0 \% / 0 \%$ threshold value for land use and soil. It should be noted that is the most detailed representation of HRUs in the SWAT model as the $0 \% / 0 \%$ threshold value does not lump any land use or soil type into another category. This resulted in a total number of 1,465 HRUs in the watershed.

The land management practices, including amount of litter and fertilizer application, timing of manure and fertilizer application, grazing intensity, and dates were obtained from a detailed review of historical nutrient management plans and interviews with 63 out of 75 farmers in the watershed since 2006 (Pennington et al. 2008). Daily precipitation and maximum and minimum temperatures were obtained from Fayetteville Weather Station located approximately $25 \mathrm{~km}$ (15.5 $\mathrm{mi})$ from the watershed. Other weather variables needed by the model (solar radiation, wind speed, and relative humidity) were estimated using the weather generator built into the SWAT model.

The SWAT outputs of interest in this study were stream flow, sediment, total $\mathrm{N}$, soluble P, and TP losses at HRU, subbasin, and watershed outlets at monthly and annual time steps. Model simulated and measured values of stream flow, sediment, total $\mathrm{N}$, mineral $\mathrm{P}$, and $\mathrm{TP}$ values were compared to validate the ability of the SWAT model to accurately simulate catchment responses. The preparation of the detailed input dataset was most time consuming but was central to the modeling BMP performance in the watershed. The SWAT model for this study was not calibrated for two reasons: the SWAT model is developed to be used in ungauged basins (Arnold et al. 1998) and a complex model, such as SWAT, can result in equifinality of parameters, which give equally good calibration objective function for more than one combination of parameters. However, it may not be known which of the parameter combinations is a true representation of the watershed characteristics. When such models are used for evaluating impacts of BMPs by further changing model parameters that correspond to the BMP under consideration, the parameter values to be changed may be drastically different from the actual watershed conditions. This may lead to unrealistic BMP effectiveness predictions. It should be noted that model inputs were based on detailed inventory of soils, land use, and land management practices in the watershed, including nutrient management plans for every field, manure and fertilizer application rates, and grazing practices in the watershed from detailed interviews of farmers (Pennington et al. 2008). Thus we felt that the input data collected represented the actual watershed conditions very closely, and there was, therefore, no need for detailed model calibration. The SWAT predictions for 2004 were used as baseline to quantify the changes in water qual- ity from various BMP combinations shown in table 1. A similar approach has been taken by other researchers to evaluate the impact of model inputs on parameter and output uncertainty (Chaubey et al. 1999a, 1999b).

Best Management Practice Scenarios. The watershed BMPs considered in this study were grouped into three categories: grazing and pasture management, riparian and buffer zones, and nutrient management. These scenarios were based on detailed interactions with the watershed stakeholders and the history of past BMPs implemented in the watershed.

Three grazing intensities including no grazing, optimum grazing, and overgrazing were considered. Based on detailed discussions with the county extension experts, the minimum plant biomass for grazing to occur was set at 2,700 and $1,009 \mathrm{~kg} \mathrm{ha}^{-1}$ $\left(2,400\right.$ and $\left.900 \mathrm{lb} \mathrm{ac}^{-1}\right)$, respectively, for optimum and overgrazing (Ron Morrow State Grazing Lands Specialist, USDA Natural Resources Conservation Service, personal communication, 2006). The overgrazing application started on September 30th and lasted for 213 days until April 30th of each year. Typically, optimum grazing comprises of rotating grazing animals through various HRUs such that a minimum biomass is maintained in the field. Given the small size of the watershed, representation of the optimum grazing application was more complex. For this study, and based on information on typical optimal grazing management, it was assumed that within 30 days the cattle should graze through the whole watershed and would stay for approximately four to six days in each pasture HRU (UAEX 2006). For example, pasture HRUs in the first 12 subbasins were scheduled to be grazed on the 1 st of the month for five days, and then cattle were moved to the next 12 subbasins on 6th of the same month. Similarly, cattle moved to the rest of the subbasins (any 12 subbasins at the same time) on the 11th, 16th, 21st and 26 th, of the month. After 30 days, the cattle went back to the first 12 subbasins again. This approach was similar to grazing operations reported in other watersheds located near the study area (White and Chaubey 2005). A dry mass daily intake of $10.14 \mathrm{~kg} \mathrm{ha}^{-1}$ day $^{-1}(9.02$

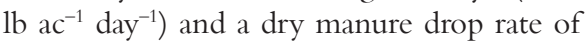
$5.85 \mathrm{~kg} \mathrm{ha}^{-1}$ day $^{-1}\left(5.21 \mathrm{lb} \mathrm{ac}^{-1}\right.$ day $\left.^{-1}\right)$ were calculated based on the numbers of cattle in the watershed and estimated typical manure (urine and feces combined) characteristics (ASABE 2005). 


\section{Table 1}

Scenario metrics of 171 simulated best management practices (BMPs) combinations based on grazing management, buffer zone management $(0,15,30 \mathrm{~m})$, and application timing (spring, summer, and fall applications), where the number indicates the litter amount ( $\mathrm{t}$ ha $\left.{ }^{-1}\right)$ unit with nonalum or alum-amended poultry litter.

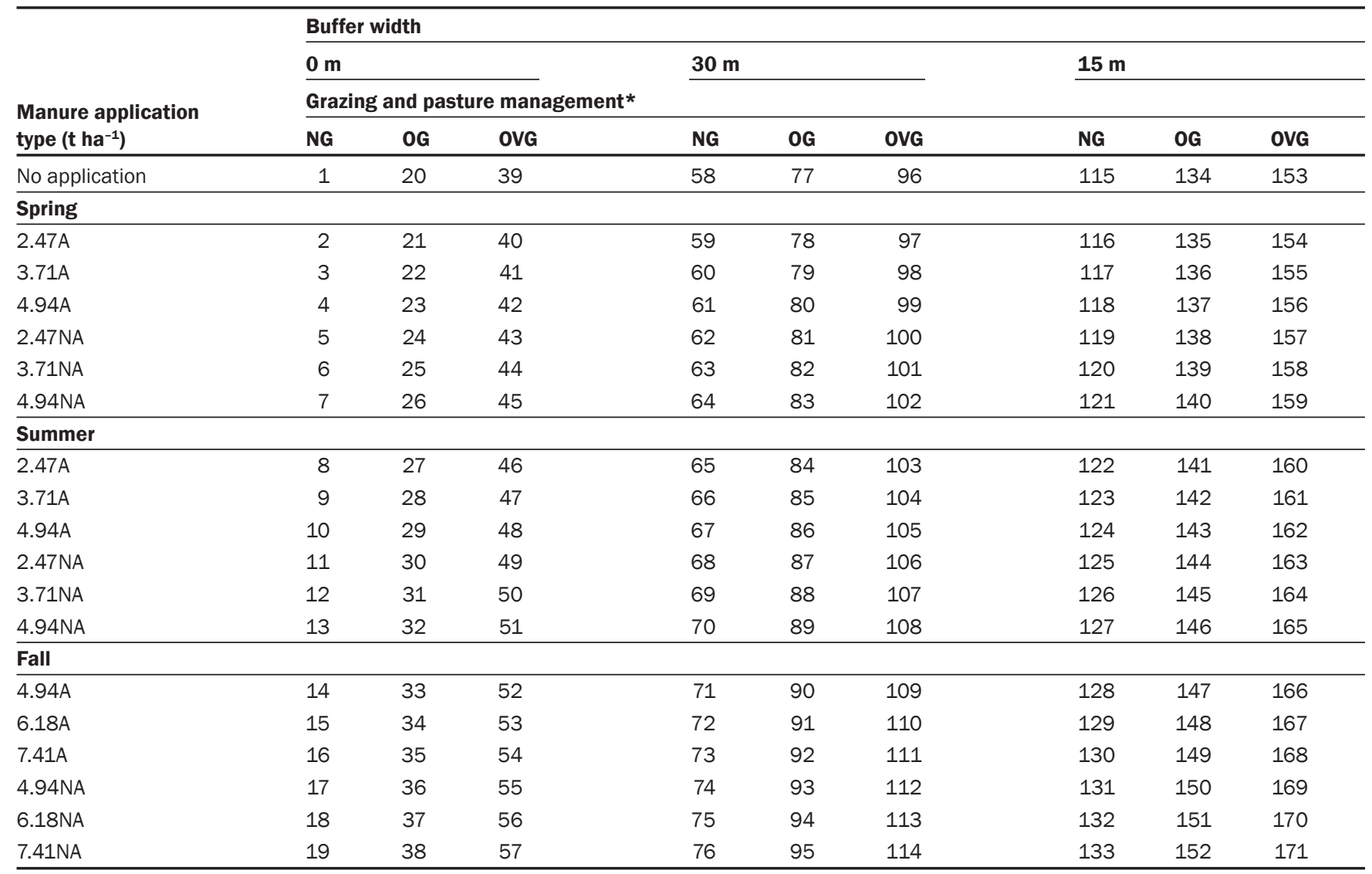

Notes: $\mathrm{NG}=$ no grazing. $\mathrm{OG}=$ optimum grazing. $\mathrm{OVG}=$ over grazing. $\mathrm{NA}=$ nonalum poultry litter. $\mathrm{A}=$ alum-amended poultry litter.

* These are numbers for various BMP scenarios and have no units associated with them.

The runoff curve number for pasture with continuous forage for grazing was 69 , 79 , and 84 under fair hydrologic conditions with hydrologic soil groups B, C, and D.The fair hydrologic condition was defined as $50 \%$ to $75 \%$ ground cover and not heavily grazed (Neitsch et al. 2004). Although intensive grazing management can possibly result in soil compaction and reduction of infiltration, the change in soil physical characteristics is not simulated in the SWAT model. A minimum plant biomass for grazing (BIO_MIN) was given to prevent a reduction of the plant biomass to a very low level, which will result in increasing erosion in the HRU. The amount of biomass trampled (BMTRMP) is very subjective, which is typically set equal to the amount of biomass consumed (BMEAT). Nutrient fractions of the manure applied during grazing were stored in the fertilizer database in the SWAT model. The manure nutrient loadings are added to the top $10 \mathrm{~mm}$
(0.39 in) of soil, which surface runoff interacts with. Therefore, the more intensive the grazing management, the greater the nutrient loadings that would be found in runoff.

Three different widths of buffer strips were modeled: 0,15 , and $30 \mathrm{~m}(0,49.2$, and $98.4 \mathrm{ft})$. It was assumed that the buffer strips were located at the end of pasture fields and received runoff from pasture areas. Many studies have used $15 \mathrm{~m}$ buffer strips to evaluate the pollutant trapping efficiency (Syverson 1995; Schmitt et al. 1999; AbuZreig et al. 2004). Other researchers have recommended riparian buffer zones greater than $30 \mathrm{~m}$ for effective subsurface nutrient reduction (Mayer et al. 2005).

The performance of the edge-of-field filter strip in the SWAT model is based on simple empirical functions of filter width (FILTERW). The filter strip trapping efficiency for sediment, nutrients, and pesticides and the reduction of nutrient loadings trans- ported in surface runoff due to the filter strip are calculated as trap $=0.367$ (FILTERW) $)^{0.2967}$ (Neitsch et al. 2004). Trapping efficiency in the form of an exponential equation indicates greater pollutant reduction in the leading edge of the filter strips, similar to the filter strip efficiency measured in pasture areas (Chaubey et al. 1995; Srivastava et al. 1996).

Nutrient management scenarios evaluated included poultry litter application rates, litter characteristics, and application timing. DeLaune et al. (2004) suggested that the litter application in pasture areas should not exceed $4.94 \mathrm{t} \mathrm{ha}^{-1}\left(2.2 \mathrm{tn} \mathrm{ac}^{-1}\right)$ for warm season grasses and $7.41 \mathrm{t} \mathrm{ha}^{-1}\left(3.31 \mathrm{tn} \mathrm{ac}^{-1}\right)$ for cool season grasses in nutrient surplus watersheds in northwest Arkansas. Therefore, the litter application rates evaluated were 2.47, 3.71, $4.94 \mathrm{t} \mathrm{ha}^{-1}\left(1.1,1.65,4.94 \mathrm{tn} \mathrm{ac}^{-1}\right)$ in spring (applied on April 30th) and summer (August 31st) to support growth of warm season grasses and 4.94, 6.18, $7.41 \mathrm{t} \mathrm{ha}^{-1}(2.2$, 
2.76, $3.31 \mathrm{tn} \mathrm{ac}^{-1}$ ) in fall (October 15th) to support growth of cool season grasses. For all application rates and timings evaluated in this study, two types of poultry litter were selected-normal poultry litter and alumamended litter. Many studies have shown that the alum-amended litter was able to reduce $\mathrm{P}$ losses in surface runoff and leaching (Shreve et al. 1995; Moore and Edwards 2007). Additionally, alum in poultry litter was shown to increase yields due to greater $\mathrm{N}$ mineralization and less ammonia emissions from litter (Moore et al. 1995; Gilmour et al. 2004; Moore and Edwards 2007). The total number of nutrient management scenarios evaluated was 18 (three nutrient application rates $\times$ three application timings $\times$ two litter types). No litter application was also added for further comparisons.

The SWAT model assumes that surface runoff interacts with the top $10 \mathrm{~mm}(0.39$ in) of soil. Thus nutrients contained in this surface layer are available for transport to the main channel in surface runoff. Based on the characteristics of the manure simulated in this study, $20 \%$ of the litter was applied to the top $10 \mathrm{~mm}$ of soil, and the remainder was applied to the 1st soil layer below $10 \mathrm{~mm}$. Based on the nutrient fractions defined in the fertilizer database in the SWAT model, the amounts of nutrient added to the different pools in the soil were calculated.

The combination of BMP factors resulted in 171 different BMP scenarios (table 1). The land management practices that existed in the watershed in 2004 were regarded as baseline (scenario 172) and were used to compare the effectiveness of selected BMP combinations in reducing NPS pollutants of concern from the watershed. Table 2 shows specific parameters in the SWAT model that were used to simulate these BMP scenarios.

Weather Simulation. Uncertainty in weather conditions was evaluated by generating 250 realizations of the weather conditions and was used to evaluate performance of various BMP scenarios listed in table 1. The weather data were generated using WXGEN (Sharpley and Williams 1990) and were based on the historical daily weather data at the Fayetteville gauging station from January 1, 1990, to April 1, 2003. The input weather data were generated for 28 years (2001 to 2028), where the first three years were used as the model warm up years, and the remaining 25 years were used to evaluate BMP performance. Weather data used to quantify

Table 2

The variables that were entered in the management files for best management practice scenarios in the Soil and Water Assessment Tool model.

\begin{tabular}{ll}
\hline Variable name & Definition \\
\hline Grazing and pasture management \\
\hline MONTH/DAY & Month/day grazing begins \\
BMEAT & Dry weight of biomass consumed daily $\left(\mathrm{kg} \mathrm{ha}^{-1} \mathrm{day}^{-1}\right)$ \\
NDGRAZ & Number of consecutive days grazing takes place in the HRU \\
BMTRMP & Dry weight of biomass trampled daily $\left(\mathrm{kg} \mathrm{ha}^{-1} \mathrm{day}^{-1}\right)$ \\
WMANURE & Dry weight of manure deposited daily $\left(\mathrm{kg} \mathrm{ha}^{-1} \mathrm{day}^{-1}\right)$ \\
IGFTYP & Manure identification code from fertilizer database
\end{tabular}

\section{Riparian and buffer zones}

FILTERW Width of edge-of-field filter strip $(\mathrm{m})$

\section{Nutrient management}

MONTH/DAY Month/day operation takes place

FERT_ID Fertilizer identification number from fertilizer database

FRT_KG Amount of fertilizer applied to HRU $\left(\mathrm{kg} \mathrm{ha}^{-1}\right)$

FRT_SURFACE Fraction of fertilizer applied to top $10 \mathrm{~mm}$ of soil

Note: $\mathrm{HRU}=$ hydrologic response units.

the impact of weather conditions on BMP performance were the same for all $171 \mathrm{BMP}$ scenarios and the baseline scenario.

High Throughput Computing with Condor. Since there were 250 weather realizations for each BMP scenario, a total of 43,000 SWAT runs were needed for 172 different management scenarios evaluated in this study. One single run of the SWAT model took 8 to 10 minutes to run on the Linux platform for this watershed and thus required at least 5,700 CPU hours to complete the 43,000 model runs. In order to make the run more efficiently, a high throughput computing system, Condor, was used to facilitate the BMP scenario runs.

Condor, a high throughput computing system for computing-intensive jobs, was developed by the University of Wisconsin (Condor Team 2007). The job-queuing mechanism allows users to submit their jobs to Condor and check job progress any time. Once the jobs are submitted, Condor distributes them onto different computer clusters and gathers the completed outputs back to the users. Condor operates on either one of two primary modes (universes): Standard universe andVanilla universe. In the Standard universe, checking points are made to allow process migration when the running process has to stop, and the program can be resumed from the checking point. However, this universe requires a link between the executable and the appropriate Condor library. It may not be suitable for use with all programs. The Vanilla universe allows the user to run jobs with or without checking points. Usually, the input files are copied to the Condor pool, Condor executes the programs, and then transfers the output files back to the user's working directory on the host computer. Also, there is no license restriction in the Vanilla universe. Thus, a Vanilla universe was used to complete SWAT runs.

The Condor Cluster of TeraGrid (TeraGrid 2008), funded by the National Science Foundation, was used to complete all 43,000 SWAT runs for this study. The SWAT runs on the TeraGrid Condor system shortened the run time to less than 30 seconds for each model run. More details about high throughput computing of the SWAT model using Condor are reported by Gitau et al. (n.d.).

Statistics Analysis (Analysis of Variance). A five-way Analysis of Variance (ANOVA) model was applied to quantify the impacts of multiple factors on total $\mathrm{N}$ and TP losses using the General Linear Models procedure in Statistical Analysis Systems (SAS Institute 2007). All variables were $\log$-transformed to meet the normality requirement of ANOVA, and a significance level $\alpha=0.01$ was used.

\section{Results and Discussion}

Comparison of Measured and Simulated Monthly Flow and Water Quality Data.A comparison of monthly measured and simulated flow, total N, TP, and sediment losses from the Upper Moores Creek from 1996 to 2007 are shown in figure 2. Stream flow was relatively higher from November to May, with June to October as low flow months. The measured mean flow ranged from 0.61 (August) to $6.27 \mathrm{~m}^{3} \mathrm{~s}^{-1}$ (January) (21.54 to 
$\left.221.43 \mathrm{ft}^{3} \mathrm{sec}^{-1}\right)$. A similar trend was observed for total N,TP, and sediment where pollutant losses were relatively higher from November to May. The monthly predicted flow by the SWAT model followed the trend of the measured flow. The predicted and measured means of sediment and nutrient losses were similar for all months $(p>0.05)$, except the predicted mean sediment from October to November and the predicted mean nitrogen from November to December were smaller than the measured mean nitrogen, indicating that the model simulated the watershed responses satisfactorily for these parameters. Harmel and Smith (2007) and Harmel et al. (2006) have argued that measured flow and water quality data from watersheds have inherent uncertainties present, and these measurement uncertainties must be considered when evaluating the watershed models. For a typical monitoring, probable error in measurement can range from $6 \%$ to $42 \%$ for flow, from $4 \%$ to $47 \%$ for dissolved nutrients, and from $4 \%$ to $50 \%$ for sediment, total $\mathrm{N}$, and TP (Harmel et al. 2006). Harmel et al. (2006) suggested that the goal of watershed modeling should not be to match the measured data with as low a deviation as possible; rather the model outputs should be expected to fall within the uncertainties inhered in the measured data. Given the statistical similarity between measured and predicted monthly flow and water quality data from 1996 to 2007 and inherent measurement uncertainty, the SWAT simulated watershed response can be considered to satisfactorily simulate actual hydrologic and water quality conditions of the study watershed.

A large variability within both measured and predicted flow and water quality data from 1996 to 2007 due to variability in the weather data and land management practices can be seen for all months. The coefficient of variability in measured flow, total $\mathrm{N}, \mathrm{TP}$, and sediment ranged from 0.5 to $2.32,0.41$ to $2.38,1.07$ to 2.5 , and 1.5 to 2.79 , respectively. Similarly, the coefficient of variability for simulated flow, total $\mathrm{N}, \mathrm{TP}$, and sediment ranged from 0.23 to $1.1,0.24$ to $1.3,0.45$ to 2 , and 0.53 to 1.77 , respectively.

Performance of Best Management Practices in Reducing Pollutant Losses. Effectiveness of 171 different BMP combinations in reducing pollutant losses from the watershed as compared to baseline conditions are shown in tables 3,4 , and 5 for total $\mathrm{N}$, mineral $\mathrm{P}$, and $\mathrm{TP}$, respectively.Values for stream flow are

\section{Figure 2}

Monthly measured and simulated flow, total sediment, total nitrogen, and total phosphorus losses from the Upper Moores Creek. Vertical lines for each month represent range of data. Solid boxes denote the 1st and 3 rd quartiles for different measured monthly data, and transparent boxes denote the 1st and 3 rd quartiles for the Soil and Water Assessment Tool simulations. The whiskers denote the maximum and minimum of the measured and simulated data.
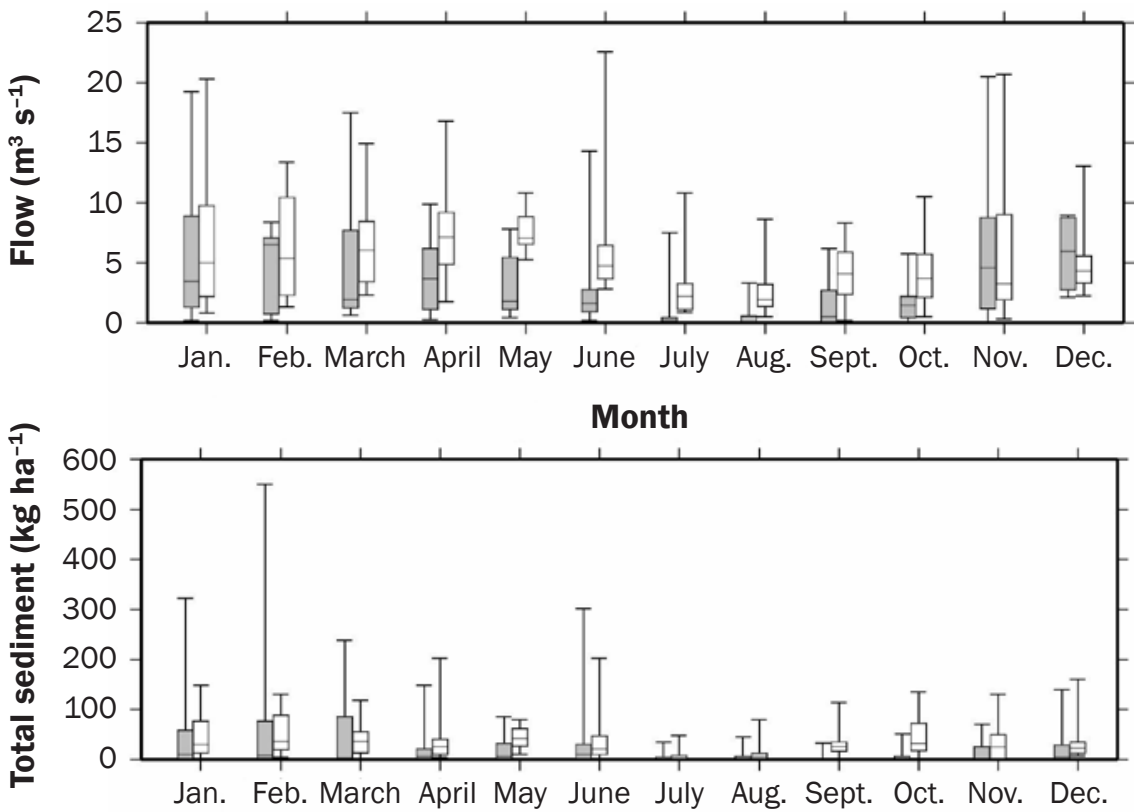

Month

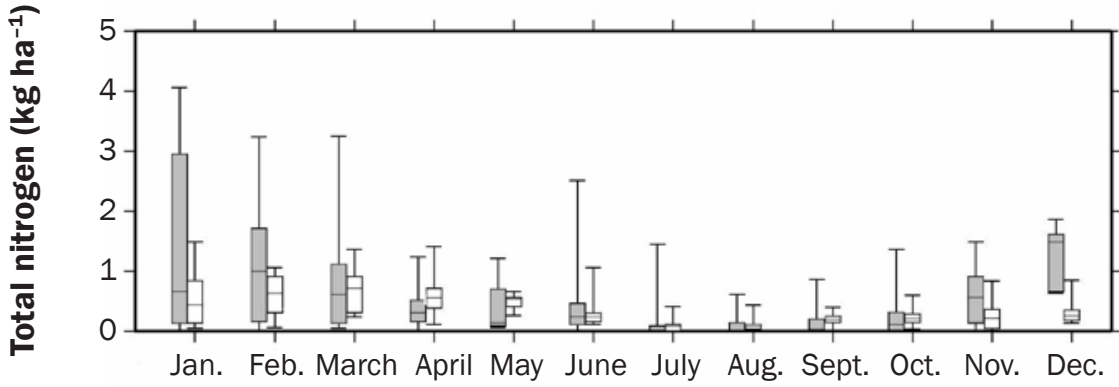

Month
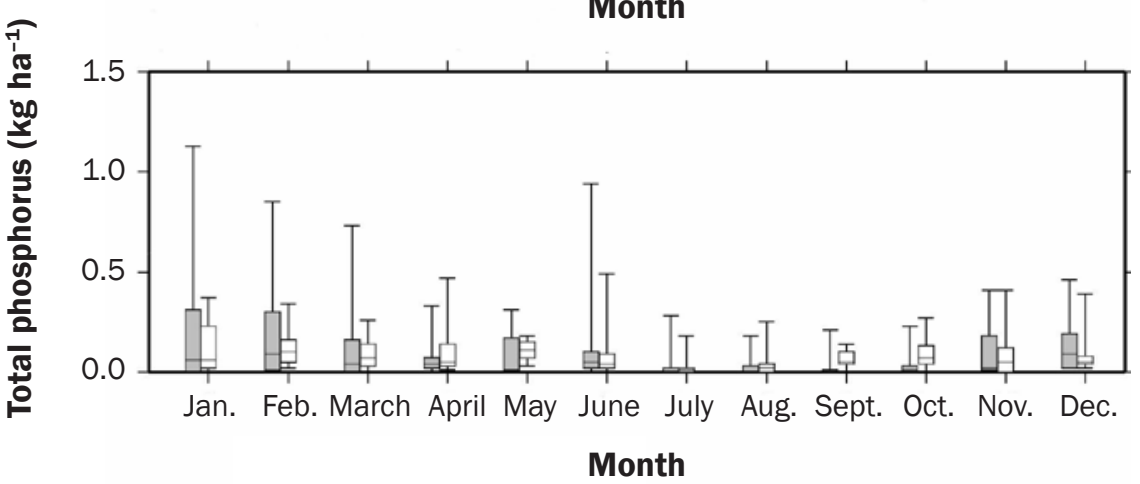

Legend

$\square$ Measured

Simulated 
Table 3

Percent difference in total nitrogen from the watershed under 171 best management practice (BMP) scenarios compared to the baseline scenario. Negative values indicate that the BMP reduced total nitrogen losses compared to the baseline condition; whereas, positive values indicate that the BMP results in increased losses of total nitrogen.

\begin{tabular}{|c|c|c|c|c|c|c|c|c|c|}
\hline \multirow{4}{*}{$\begin{array}{l}\text { Manure application } \\
\text { type }\left(\mathrm{t} \mathrm{ha}^{-1}\right)\end{array}$} & \multicolumn{9}{|c|}{ Buffer width } \\
\hline & $\mathbf{O m}$ & & & $15 \mathrm{~m}$ & & & $30 \mathrm{~m}$ & & \\
\hline & \multicolumn{9}{|c|}{$\overline{\text { Grazing and pasture management }}$} \\
\hline & NG (\%) & $O G(\%)$ & OVG (\%) & NG (\%) & $O G(\%)$ & OVG (\%) & NG (\%) & OG (\%) & OVG (\%) \\
\hline No application & -37.2 & -35.2 & -7.5 & -44.7 & -42.5 & -36.1 & -46.3 & -46.1 & -42.8 \\
\hline \multicolumn{10}{|l|}{ Spring } \\
\hline $2.47 \mathrm{~A}$ & -32.7 & -30.7 & -12.8 & -43.2 & -41.2 & -35.8 & -45.9 & -45.5 & -41.1 \\
\hline $3.71 \mathrm{~A}$ & -29.8 & -27.9 & -11.6 & -42.3 & -40.1 & -34.7 & -45.3 & -44.9 & -40.1 \\
\hline $4.94 \mathrm{~A}$ & -26.8 & -25.2 & -8.8 & -41.3 & -38.9 & -32.9 & -44.6 & -43.9 & -38.6 \\
\hline $2.47 \mathrm{NA}$ & -32.8 & -30.3 & -10.5 & -43.3 & -42.4 & -35.3 & -45.6 & -45.5 & -41.2 \\
\hline $3.71 \mathrm{NA}$ & -30.6 & -28.3 & -9.5 & -42.5 & -42.0 & -34.4 & -45.4 & -45.0 & -40.3 \\
\hline 4.94NA & -28.7 & -26.5 & -7.8 & -41.8 & -41.1 & -33.3 & -45.0 & -44.6 & -39.5 \\
\hline \multicolumn{10}{|l|}{ Summer } \\
\hline $2.47 \mathrm{~A}$ & -31.9 & -28.4 & 3.3 & -41.6 & -38.6 & -28.9 & -44.0 & -42.8 & -36.9 \\
\hline $3.71 \mathrm{~A}$ & -26.5 & -22.8 & 9.9 & -38.4 & -34.9 & -24.9 & -41.1 & -39.6 & -33.0 \\
\hline $4.94 \mathrm{~A}$ & -21.3 & -17.3 & 16.0 & -34.8 & -31.5 & -21.0 & -38.2 & -36.7 & -29.6 \\
\hline $2.47 \mathrm{NA}$ & -31.9 & -28.6 & 3.4 & -41.7 & -40.6 & -29.5 & -44.0 & -43.4 & -37.6 \\
\hline $3.71 \mathrm{NA}$ & -27.7 & -23.7 & 9.7 & -39.4 & -37.5 & -25.3 & -41.9 & -40.6 & -33.9 \\
\hline 4.94NA & -22.6 & -18.3 & 16.1 & -35.8 & -33.6 & -21.4 & -38.8 & -37.5 & -30.5 \\
\hline \multicolumn{10}{|l|}{ Fall } \\
\hline $4.94 \mathrm{~A}$ & -14.0 & -10.2 & 19.7 & -27.8 & -25.9 & -13.5 & -31.1 & -29.7 & -21.9 \\
\hline $6.18 \mathrm{~A}$ & -6.4 & -2.0 & 27.1 & -21.7 & -18.8 & -7.4 & -25.4 & -23.9 & -15.3 \\
\hline $7.41 \mathrm{~A}$ & 2.0 & 6.4 & 33.5 & -14.7 & -12.5 & -0.8 & -19.3 & -16.8 & -8.7 \\
\hline 4.94NA & -12.2 & -8.0 & 24.3 & -25.8 & -23.9 & -10.8 & -29.1 & -27.9 & -19.7 \\
\hline 6.18NA & -4.1 & 0.2 & 32.2 & -19.4 & -17.1 & -4.3 & -23.3 & -21.8 & -13.8 \\
\hline 7.41NA & 4.0 & 8.5 & 38.9 & -12.8 & 8.6 & 2.5 & -17.3 & -15.7 & -6.5 \\
\hline
\end{tabular}

Notes: $\mathrm{NG}=$ no grazing. $\mathrm{OG}=$ optimum grazing. $\mathrm{OVG}=$ over grazing. $\mathrm{NA}=$ nonalum poultry litter. $\mathrm{A}=$ alum-amended poultry litter. The percent reduction was calculated as the median of each of 171 BMP scenarios minus the median of the baseline scenario and was then divided by the median of the baseline scenario.

not shown since none of the BMPs evaluated were targeted specifically to affect flow in the watershed. It should be noted that the values shown in these tables are the median values from 250 different weather realizations and can be considered as the average watershed response under these BMP scenarios. A negative value in these tables indicates that the $\mathrm{BMP}$ reduced the pollutant losses compared to the baseline condition; whereas, a positive value indicates that the BMP results in increased losses of pollutants. Overgrazing resulted in increased losses of total $\mathrm{N}$ from the watershed for all litter application rates, application timings, and buffer widths (table 3). Generally, total $N$ losses increased with grazing intensity and litter application rates. Minimum reductions in total $\mathrm{N}$ losses were predicted for litter applications in fall for all application rates. However, poultry litter application in spring resulted in the greatest reduction of total $\mathrm{N}$ losses for all application rates. Buffer strips located below the pasture areas decreased total $\mathrm{N}$ losses significantly. In general, $30 \mathrm{~m}$ (98.4 ft) buffer strips were more effective in reducing total $\mathrm{N}$ losses compared to $15 \mathrm{~m}$ (49.2 ft) buffer strips.

Table 4 shows the percent reduction/ increase in mineral P losses from the watershed under 171 BMPs scenarios evaluated in this study. For no grazing and optimum grazing conditions, the mineral $\mathrm{P}$ reductions ranged from $9 \%$ to $71 \%$ from the watershed. Overgrazing resulted in increased losses of mineral $\mathrm{P}$ for all litter application rates, timings, and chemical amendments when no buffer strips were present in the watershed. The mineral $\mathrm{P}$ losses increased up to $40 \%$ for overgrazed conditions. In general, both

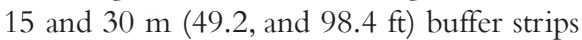
decreased the losses of mineral $\mathrm{P}$ from the watershed, ranging from $51 \%$ to $71 \%$. For all litter application rates and application timings, slightly smaller losses of mineral
$\mathrm{P}$ were predicted for litter amended with alum, primarily because alum-amended litter reduced the soluble $\mathrm{P}$ losses from the pasture area. Moore et al. (2007) have reported that poultry litter amended with alum reduces availability of soluble $\mathrm{P}$, thus reducing the runoff losses from pasture areas.

A similar trend in BMP effectiveness in reducing the losses of TP from the watershed was predicted by the SWAT model (table 5). Similar to total $\mathrm{N}$ and mineral $\mathrm{P}$ losses, increased grazing intensity and litter application rates resulted in increased losses of TP from the pasture areas. Similarly, reductions in TP losses were very similar for spring and summer applications but were significantly greater than TP reductions when poultry litter was applied in fall $(p<0.1)$. Similar to TN losses, overgrazing resulted in increased losses of TP from pasture areas for overgrazed conditions, compared to baseline, when no filter strips were present below the pasture areas. 
Table 4

Percent difference in mineral phosphorus from the watershed under 171 best management practice (BMP) scenarios compared to the baseline scenario. Negative values indicate that the BMP reduced mineral phosphorus losses compared to the baseline condition; whereas, positive values indicate that the BMP results in increased losses of mineral phosphorus.

\begin{tabular}{|c|c|c|c|c|c|c|c|c|c|}
\hline \multirow{3}{*}{$\begin{array}{l}\text { Manure application } \\
\text { type }\left(\mathrm{t} \mathrm{ha}^{-1}\right)\end{array}$} & \multicolumn{9}{|c|}{ Buffer width } \\
\hline & \multicolumn{3}{|c|}{$\underline{0 \mathrm{~m}}$} & \multicolumn{3}{|l|}{$15 \mathrm{~m}$} & \multicolumn{3}{|l|}{$30 \mathrm{~m}$} \\
\hline & \multicolumn{9}{|c|}{ Grazing and pasture management } \\
\hline No application & -56.0 & -48.8 & -7.7 & -68.3 & -67.6 & -59.8 & -71.3 & -71.2 & -71.3 \\
\hline \multicolumn{10}{|l|}{ Spring } \\
\hline $4.94 \mathrm{~A}$ & -26.0 & -21.2 & 7.4 & -63.1 & -62.8 & -57.0 & -71.3 & -71.1 & -71.2 \\
\hline $2.47 \mathrm{NA}$ & -32.7 & -28.7 & 2.5 & -64.1 & -63.3 & -57.8 & -70.9 & -71.0 & -71.0 \\
\hline 3.71NA & -23.5 & -20.2 & 11.1 & -62.4 & -61.9 & -56.1 & -70.9 & -70.9 & -71.1 \\
\hline 4.94NA & -14.9 & -10.7 & 19.5 & -60.9 & -60.2 & -54.5 & -70.9 & -71.0 & -71.1 \\
\hline \multicolumn{10}{|l|}{ Summer } \\
\hline 3.71NA & -26.2 & -21.5 & 17.7 & -63.1 & -62.0 & -55.0 & -70.9 & -70.9 & -71.1 \\
\hline 4.94NA & -17.2 & -12.6 & 27.0 & -61.2 & -60.4 & -53.5 & -70.9 & -71.0 & -71.1 \\
\hline \multicolumn{10}{|l|}{ Fall } \\
\hline $4.94 \mathrm{~A}$ & -25.3 & -21.0 & 14.4 & -62.9 & -62.2 & -56.0 & -71.4 & -71.3 & -71.3 \\
\hline $6.18 \mathrm{~A}$ & -19.4 & -14.7 & 19.4 & -61.7 & -60.7 & -55.2 & -71.4 & -71.3 & -71.4 \\
\hline $7.41 \mathrm{~A}$ & -13.1 & -8.8 & 23.7 & -60.7 & -59.9 & -54.3 & -71.4 & -71.1 & -71.4 \\
\hline 4.94NA & -16.3 & -11.8 & 25.1 & -61.2 & -60.2 & -53.8 & -70.9 & -71.1 & -71.0 \\
\hline $6.18 \mathrm{NA}$ & -8.1 & -3.6 & 32.4 & -59.6 & -58.8 & -52.4 & -71.0 & -71.0 & -71.0 \\
\hline 7.41NA & -0.1 & 4.4 & 39.8 & -58.3 & -60.9 & -51.1 & -71.0 & -71.1 & -71.1 \\
\hline
\end{tabular}

Notes: $\mathrm{NG}=$ no grazing. $\mathrm{OG}=$ optimum grazing. $\mathrm{OVG}=$ over grazing. $\mathrm{NA}=$ nonalum poultry litter. $\mathrm{A}=$ alum-amended poultry litter. The percent reduction was calculated as the median of each of 171 BMP scenarios minus the median of the baseline scenario and was then divided by the median of the baseline scenario.

However, both 15 and $30 \mathrm{~m}(49.2$, and 98.4 ft) buffer strips reduced the TP losses significantly from the pasture areas. The SWAT model predicted that $30 \mathrm{~m}$ buffers would reduce TP losses by $66 \%$ from the watershed. Chaubey et al. (1995), based on simulated rainfall studies in Arkansas, have reported that $21 \mathrm{~m}(69 \mathrm{ft})$ buffer strips reduced TP losses by $92 \%$.

Interactions of Best Management Practices in Reducing Pollutant Losses. One of the goals of the CEAP program is to evaluate how various BMPs, when implemented together, interact synergistically or counteractively. Interactions among all $171 \mathrm{BMP}$ scenarios were evaluated using a five-way ANOVA to quantify the impacts of five factors (litter application rate, litter characteristics, litter application timing, grazing management, and buffer management) on total $\mathrm{N}$ and TP losses. The predicted losses of nutrients for each BMP scenario were log-transformed to meet the normality requirements of the ANOVA. The coefficient of determination $\left(r^{2}\right)$ values of each ANOVA model were significant $(p<$ $0.0001)$ with corresponding values of 0.65 and 0.97 for total $\mathrm{N}$ and TP, respectively.

Figure 3 shows the interaction effects of litter rates, characteristics, application timings, grazing management, and buffer management on total $\mathrm{N}$, and TP losses. The dashed lines were the simulation results of BMP scenarios with no nutrient management. Overall, total $\mathrm{N}$ and TP losses increased as the litter amount increased. Fall litter application resulted in the greatest TN losses (figure $3 \mathrm{a}$ ). The influence of fall litter application was emphasized along with overgrazing management. When compared with the BMP scenarios with no buffer strips, overgrazing resulted in significantly greater total $\mathrm{N}$ and TP losses $(p<0.1)$. The timing of litter application significantly affected total $\mathrm{N}$ losses, with the greatest amount of total $\mathrm{N}$ losses associated with the litter application in fall $(p<0.1)$. However, the timing of the litter application has relatively minor impacts on TP losses. Total phosphorus losses were similar for spring and summer litter application for both optimum and overgrazing conditions.

The impacts of litter amount, timing of application, and grazing intensity on nutrient losses became less distinguishable when buffer strips were installed below pasture areas. Both 15 and $30 \mathrm{~m}$ (49.2, and $98.4 \mathrm{ft}$ ) buffer strips significantly reduced the losses of total $\mathrm{N}$ and TP. Nutrient losses generally decreased with an increase in buffer width and a decrease in grazing intensity.

Table 6 shows the top 10 individual or combinations of BMPs that could be applied in the watershed to reduce losses of nutrients from pasture areas. Buffer strips were the most important BMPs affecting the losses of TP from the pasture areas where it accounted for $99 \%$ of total reduction efficiency, while litter 


\section{Table 5}

Percent difference in total phosphorus from the watershed under 171 best management practice (BMP) scenarios compared to the baseline scenario. Negative values indicate that the BMP reduced total phosphorus losses compared to the baseline condition; whereas, positive values indicate that the BMP results in increased losses of total phosphorus.

\begin{tabular}{|c|c|c|c|c|c|c|c|c|c|}
\hline \multirow{4}{*}{$\begin{array}{l}\text { Manure application } \\
\text { type }\left(\mathrm{t} \mathrm{ha}^{-1}\right)\end{array}$} & \multicolumn{9}{|c|}{ Buffer width } \\
\hline & $\mathbf{0 ~ m}$ & & & $15 \mathrm{~m}$ & & & $30 \mathrm{~m}$ & & \\
\hline & \multicolumn{9}{|c|}{$\overline{\text { Grazing and pasture management }}$} \\
\hline & NG (\%) & $O G(\%)$ & OVG (\%) & NG (\%) & OG (\%) & OVG (\%) & NG (\%) & OG (\%) & OVG (\%) \\
\hline No application & -46.2 & -39.3 & 16.1 & -61.9 & -60.5 & -49.9 & -65.5 & -65.4 & -65.6 \\
\hline \multicolumn{10}{|l|}{ Spring } \\
\hline $2.47 \mathrm{~A}$ & -28.0 & -24.8 & 11.3 & -58.5 & -57.6 & -51.0 & -65.6 & -65.5 & -65.5 \\
\hline $3.71 \mathrm{~A}$ & -21.8 & -17.6 & 15.3 & -57.4 & -56.3 & -50.5 & -65.6 & -65.5 & -65.6 \\
\hline $4.94 \mathrm{~A}$ & -15.0 & -10.6 & 21.0 & -56.1 & -55.1 & -49.4 & -65.6 & -65.3 & -65.5 \\
\hline $2.47 \mathrm{NA}$ & -22.8 & -18.2 & 22.0 & -57.4 & -56.2 & -48.7 & -65.1 & -65.2 & -65.2 \\
\hline 3.71NA & -14.1 & -10.1 & 29.7 & -55.5 & -54.9 & -47.2 & -65.1 & -65.1 & -65.3 \\
\hline 4.94NA & -5.9 & -1.2 & 37.2 & -54.0 & -53.3 & -46.0 & -65.1 & -65.2 & -65.3 \\
\hline \multicolumn{10}{|l|}{ Summer } \\
\hline $2.47 \mathrm{~A}$ & -30.3 & -25.1 & 35.5 & -59.1 & -57.6 & -46.4 & -65.5 & -65.3 & -65.6 \\
\hline $3.71 \mathrm{~A}$ & -23.1 & -17.0 & 47.2 & -57.8 & -56.2 & -44.3 & -65.5 & -65.3 & -65.5 \\
\hline $4.94 \mathrm{~A}$ & -15.9 & -9.7 & 56.9 & -56.4 & -54.8 & -42.6 & -65.6 & -65.4 & -65.6 \\
\hline $2.47 \mathrm{NA}$ & -26.0 & -20.0 & 44.0 & -58.0 & -56.8 & -44.3 & -65.1 & -65.1 & -65.3 \\
\hline 3.71NA & -17.4 & -10.8 & 56.4 & -56.5 & -54.8 & -42.1 & -65.1 & -65.1 & -65.2 \\
\hline 4.94NA & -8.6 & -1.9 & 68.3 & -54.5 & -53.1 & -40.0 & -65.1 & -65.1 & -65.3 \\
\hline \multicolumn{10}{|l|}{$\overline{\text { Fall }}$} \\
\hline $4.94 \mathrm{~A}$ & -16.5 & -10.6 & 45.4 & -56.4 & -55.3 & -44.5 & -65.6 & -65.6 & -65.5 \\
\hline $6.18 \mathrm{~A}$ & -10.7 & -4.9 & 48.6 & -55.1 & -53.8 & -44.1 & -65.6 & -65.6 & -65.6 \\
\hline $7.41 \mathrm{~A}$ & -4.9 & 0.6 & 49.8 & -54.3 & -53.1 & -43.9 & -65.6 & -65.4 & -65.6 \\
\hline 4.94NA & -8.9 & -2.4 & 58.7 & -54.8 & -53.3 & -41.6 & -65.1 & -65.3 & -65.3 \\
\hline 6.18NA & -0.9 & 5.7 & 65.1 & -53.1 & -51.8 & -40.3 & -65.2 & -65.2 & -65.3 \\
\hline 7.41NA & 6.1 & 12.7 & 69.3 & -51.9 & -55.5 & -39.5 & -65.2 & -65.3 & -65.4 \\
\hline
\end{tabular}

Notes: $\mathrm{NG}=$ no grazing. $\mathrm{OG}=$ optimum grazing. $\mathrm{OVG}=$ over grazing. $\mathrm{NA}=$ nonalum poultry litter. $\mathrm{A}=$ alum-amended poultry litter. The percent reduction was calculated as the median of each of 171 BMP scenarios minus the median of the baseline scenario and was then divided by the median of the baseline scenario.

application timing, buffer strips, and grazing management were the three most important BMPs affecting the losses of total $\mathrm{N}$ where they accounted for $29 \%, 28 \%, 28 \%$ of total reduction efficiency, respectively. Other individual BMPs affecting the losses of total $\mathrm{N}$ included the amount applied and whether or not a chemical amendment was added to the poultry litter. The interaction between the timing of litter application and buffer strips was the most important factor affecting total N losses. Similarly, TP transport was most affected by interactions between filter strips and grazing management.

Uncertainty in Best Management Practice Performance due to Weather Uncertainty. Variability in weather data, such as precipitation and temperature, can strongly affect predicted performance of BMPs (Garbrecht 2008; Garbrecht et al. 2006). We quantified the uncertainty due to variability in weather conditions by considering 250 possible

\section{Table 6}

Top 10 important best management practices (BMPs) and combinations of BMPs for analysis of variance (ANOVA) models of total nitrogen and total phosphorus.

\begin{tabular}{llllr}
\hline Rank & Total nitrogen & Percent & Total phosphorus & Percent \\
\hline 1 & Time & 29.45 & Buffer & 99.22 \\
2 & Buffer & 28.27 & Grazing & 0.45 \\
3 & Grazing & 27.90 & Buffer $\times$ grazing & 0.22 \\
4 & Smount & 8.45 & Amount & 0.03 \\
5 & Time $\times$ buffer & 2.40 & Amount $\times$ buffer & 0.02 \\
6 & Time $\times$ grazing & 0.80 & Time $\times$ grazing & 0.01 \\
7 & Time $\times$ amount & 0.73 & Type & 0.01 \\
8 & Amount $\times$ grazing & 0.52 & Time $\times$ buffer $\times$ grazing & 0.01 \\
9 & Time $\times$ buffer $\times$ grazing & 0.42 & Type $\times$ buffer & 0.01 \\
10 & Amount $\times$ buffer & 0.38 & Time & 0.01 \\
\hline
\end{tabular}

Note: All $p$-values are $<0.0001$.

realizations of weather data for a 25 -year simulation period. This approach is similar to the Monte Carlo estimate of model uncertainty, where many possible values of a parameter are drawn from a sample space (Migliaccio and Chaubey 2008). Figure 4 


\section{Figure 3}

The interaction effects of litter rate, litter characteristics, litter application timing, grazing and buffer management on (a) total nitrogen (kg ha $\left.{ }^{-1}\right)$ and (b) total phosphorus $\left(\mathrm{kg} \mathrm{ha}^{-1}\right)$ losses.

(a)

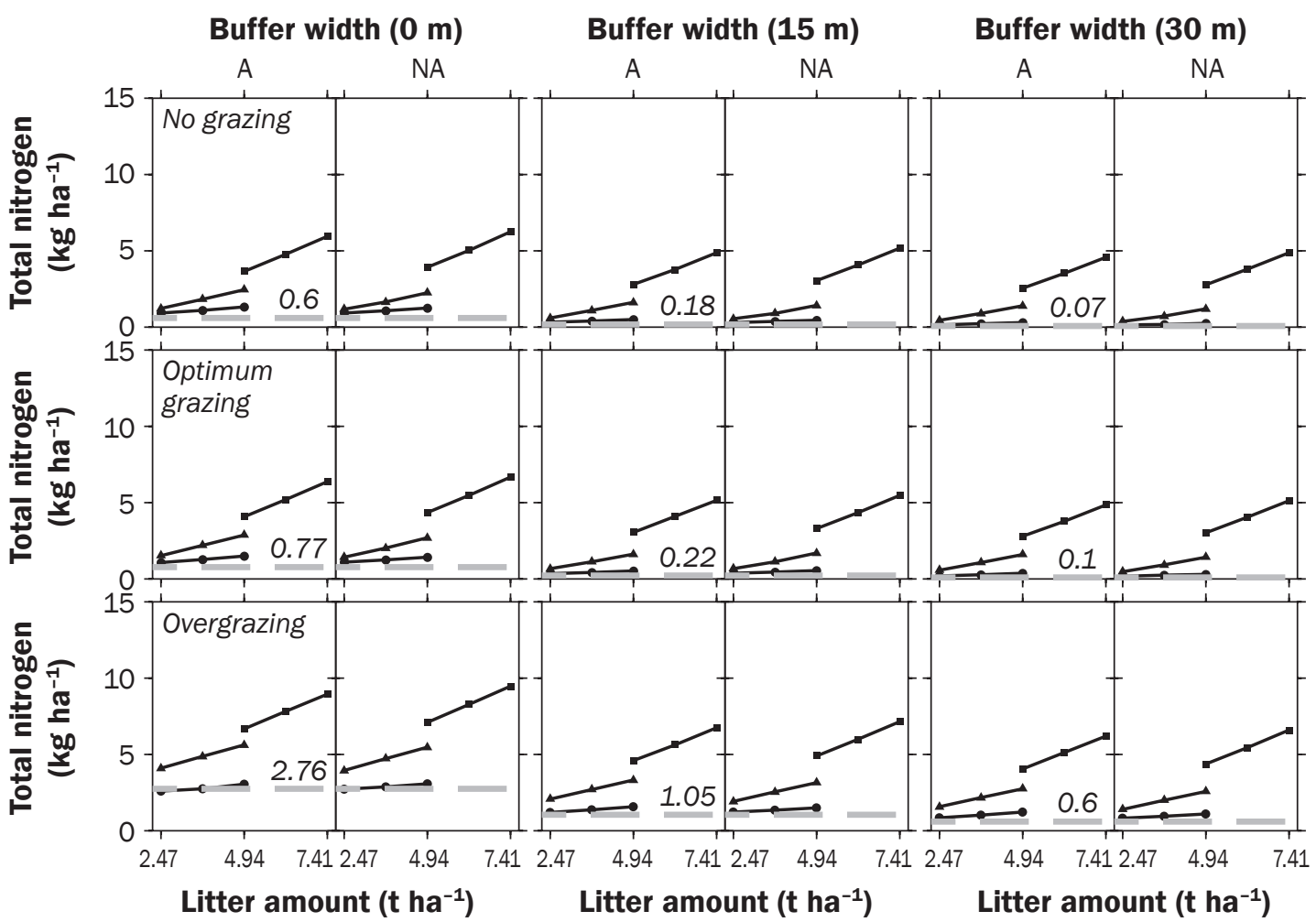

(b)

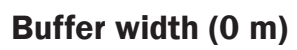

Buffer width (15 m)

Buffer width (30 m)

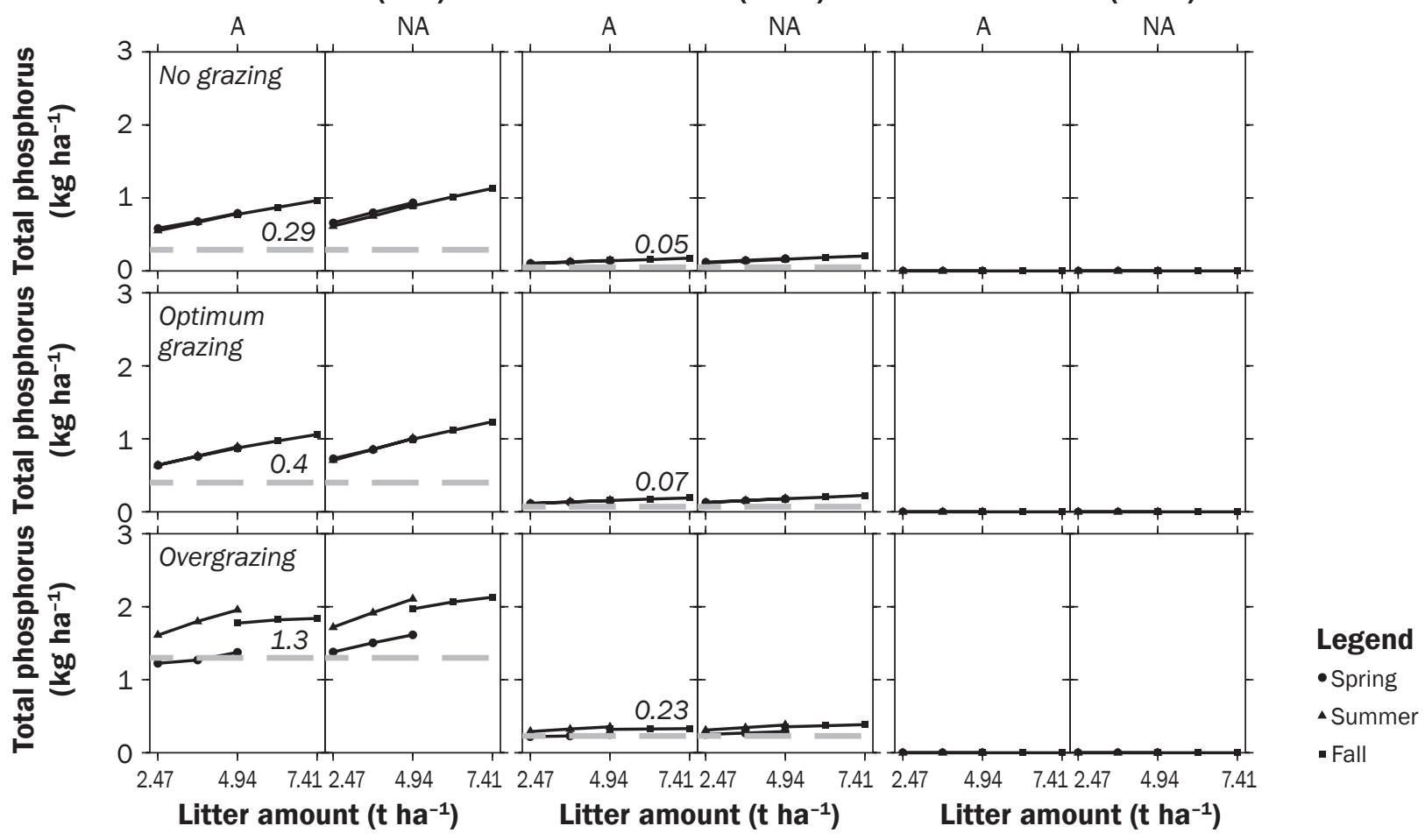

Notes: $\mathrm{A}=$ alum-amended litter. NA = poultry litter. The dashed lines are the simulations with no litter application. 
shows a comparison of the historical measured and simulated precipitation, minimum temperature, and maximum temperature for each month for the watershed. The simulated minimum and maximum temperature closely followed the trend of measured data for each month $(p>0.05)$. The means of the simulated precipitation for months April through August and October were similar to the means of the measured precipitation $(p>0.05)$, while the means of simulated precipitation for other months were significantly lower than the measured precipitation $(p<0.05)$. However, a greater variability in the simulated weather data was seen compared to the measured data.This was expected due to differences in the weather record for measured and simulated data. Measured data were for 13 years from 1990 to 2002, whereas the simulated data represented 25 years (2004 to 2028). As the simulation period increased, variability in the weather conditions can be expected to increase.

Figure 5 uses box and whisker plots to show uncertainty in BMP performance due to weather uncertainty for total $\mathrm{N}$, mineral $\mathrm{P}$, and TP losses from the watershed for each of 171 BMP scenarios evaluated in this study. Box plots show medians and 1st and 3 rd quartile values. Whiskers show 10th and 90th percentile values of pollutant losses under each BMP scenario. For each pollutant, dashed horizontal lines represent median and 90th percentile values of pollutant losses under baseline conditions. Figure 5 shows that weather uncertainty affects pollutant transport from the watershed for all BMP scenarios.Variability in the baseline estimates ranged from 1.12 to $4.04 \mathrm{~kg} \mathrm{ha}^{-1}$ (1 to 3.60

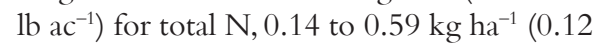
to $\left.0.53 \mathrm{lb} \mathrm{ac}^{-1}\right)$ for mineral $\mathrm{P}$, and 0.26 to $1.09 \mathrm{~kg} \mathrm{ha}^{-1}$ (0.23 to $\left.0.97 \mathrm{lb} \mathrm{ac}^{-1}\right)$ for TP, respectively. A large variability in baseline estimates indicates that even if no changes are made in the watershed, pollutant losses will vary considerably depending upon the weather conditions. These results are similar to the data presented by Garbrecht et al. (2006) for a CEAP watershed in Oklahoma for which the authors showed that 33\% variability in rainfall can result in 100\% variability in runoff and $183 \%$ variability in sediment transport. A comparison of the pollutant losses under various BMPs scenarios suggests that many of the individual and combinations of BMPs will reduce the pollutant losses from the watershed compared to the current

\section{Figure 4}

Comparison of monthly measured (1990 to 2002) and simulated (2004 to 2028) precipitation and minimum and maximum temperature data used in best management practice performance analyses of Soil and Water Assessment Tool model. Solid boxes denote the 1st and 3 rd quartiles for 13 different measured monthly data, and transparent boxes denote the 1 st and 3 rd quartiles for 6,250 different monthly realizations ( 25 years $\times 250$ weather realizations) used to quantify stochasticity in weather data. Whiskers for each month represent the 1oth and goth percentiles of the data, and the dots represent the outliers. Solid lines denote the mean of the measured monthly data, and dashed lines denote the mean of simulated monthly data.
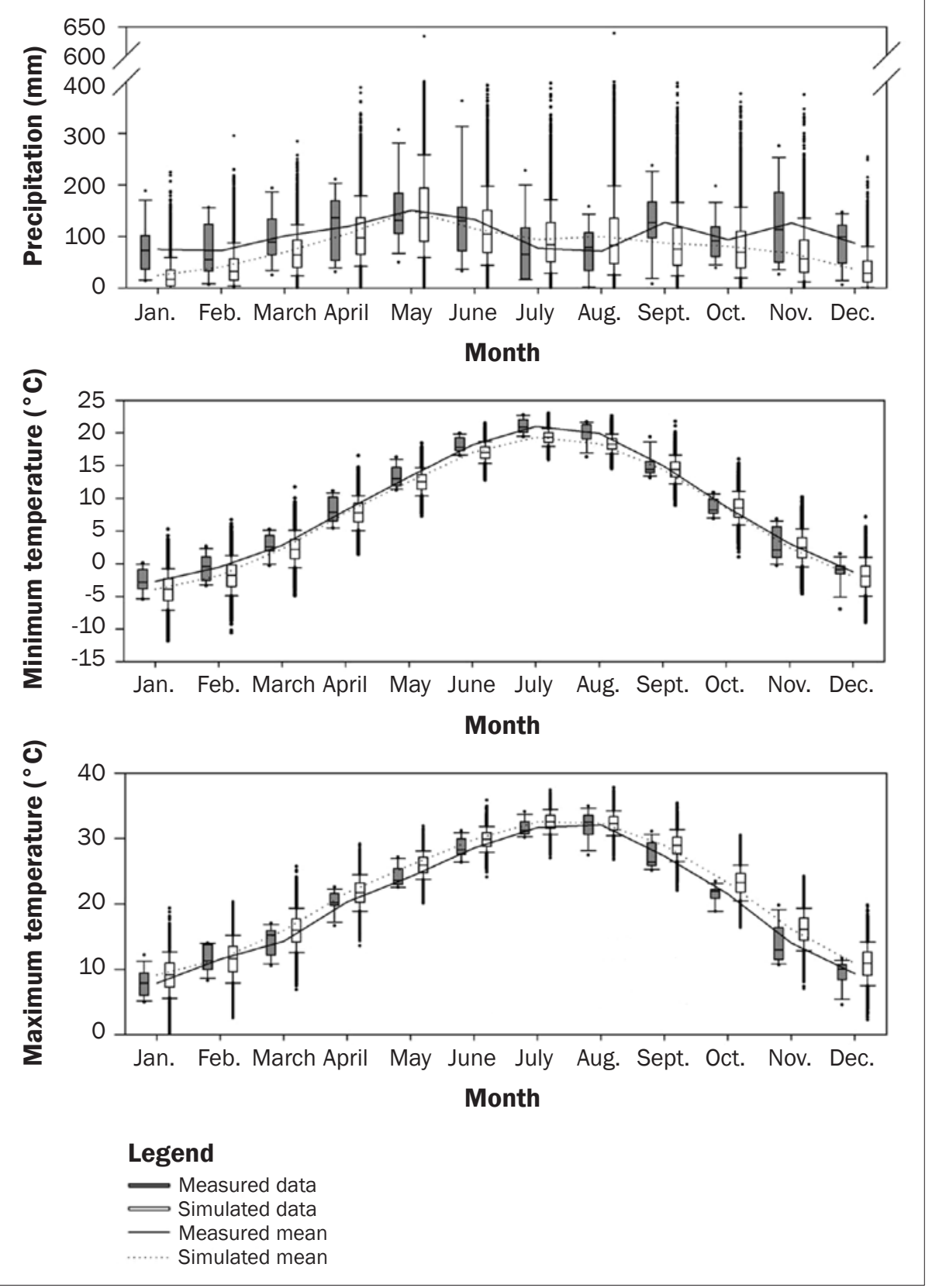

conditions. This presents multiple options for watershed managers and farmers to consider for reducing losses of $\mathrm{N}$ and $\mathrm{P}$ from the watershed. However, when the uncertainty in the weather conditions are considered, 3rd quartile and 90th percentile values exceed the baseline median values for many of these BMPs (for example see BMP scenarios 1 to 57), indicating that during certain weather conditions, the pollutant loads may exceed the baseline values, suggesting that the BMPs would not work in the watershed. 


\section{Figure 5}

Annual total nitrogen $\left(\mathrm{kg} \mathrm{ha}^{-1}\right)$, mineral phosphorus $\left(\mathrm{kg} \mathrm{ha}^{-1}\right)$, and total phosphorus losses $\left(\mathrm{kg} \mathrm{ha}^{-1}\right)$ from the Lincoln Lake watershed under 171 best management practice (BMP) scenarios and the baseline scenario. Vertical lines for each scenario represent the uncertainty in BMP performance due to weather uncertainty. Solid boxes denote the 1st and 3 rd quartiles for 6,250 different annual simulations ( 25 years $\times 250$ weather realizations), and the whiskers denote the 1oth and 90 th percentiles for 6,250 annual simulations.
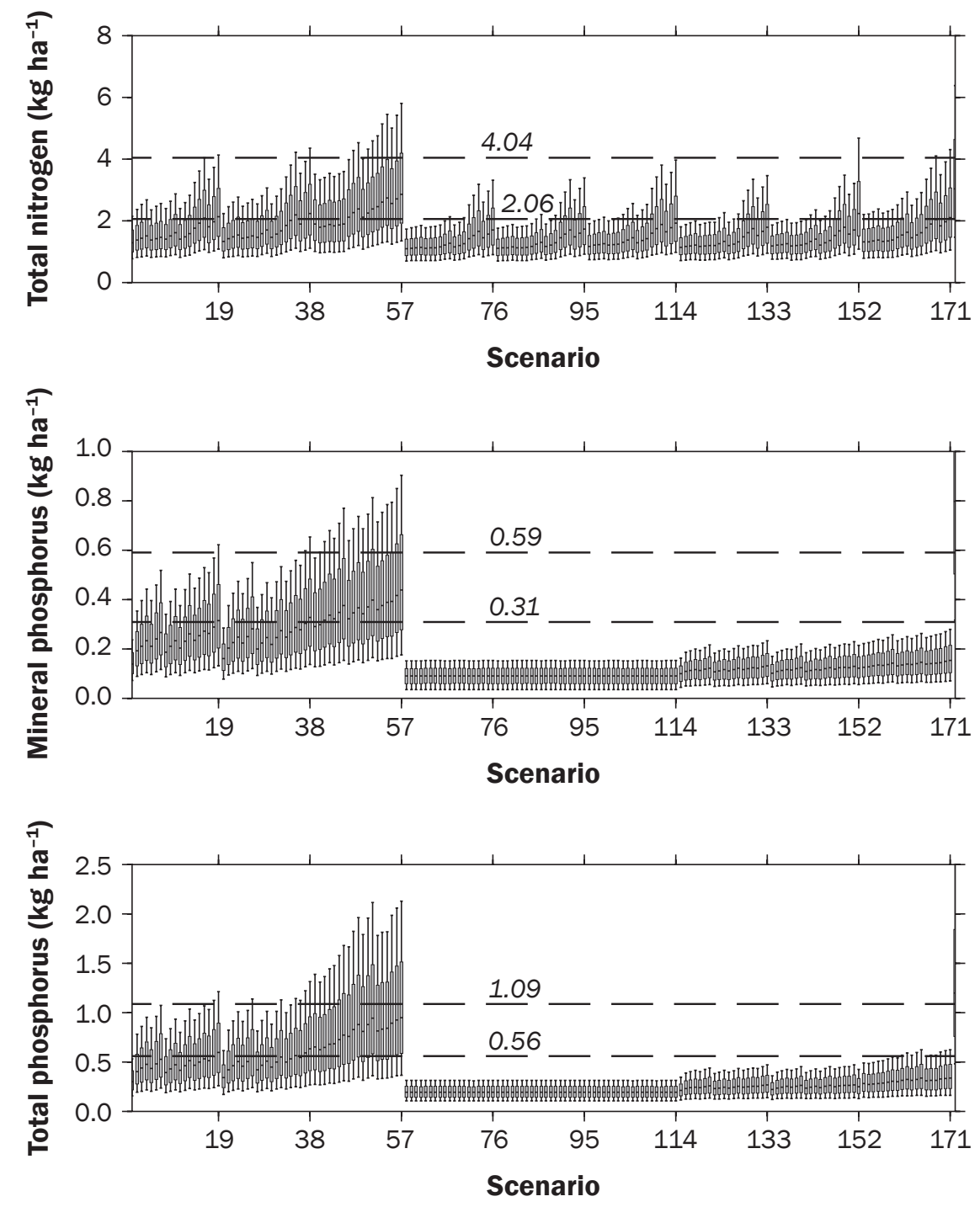

Note: The marked values are the 90th percentile and median of the baseline scenario (scenario 172).

A comparison of variability in pollutant losses for overgrazed conditions (scenarios 39 to 57 in figure 5) indicates that pollutant losses exceeded the baseline values for most of the weather events. The 90th percentile values for these scenarios were much greater than the 90th percentile values obtained for the baseline conditions. When all BMP scenarios were compared with the baseline scenario for each simulated weather condition, weather induced variation in the performance of BMPs in reducing total $\mathrm{N}$ losses ranged from -2.33 to $0.59 \mathrm{~kg} \mathrm{ha}^{-1}$ $\left(-2.07\right.$ to $\left.0.53 \mathrm{lb} \mathrm{ac}^{-1}\right)$, from -2.31 to $1.23 \mathrm{~kg}$ $\mathrm{ha}^{-1}\left(-2.06\right.$ to $\left.1.09 \mathrm{lb} \mathrm{ac}^{-1}\right)$ and from -2.14 to $1.99 \mathrm{~kg} \mathrm{ha}^{-1}$ (-1.90 to $\left.1.77 \mathrm{lb} \mathrm{ac}^{-1}\right)$ for no grazing, optimum grazing, and overgrazing management, respectively. Similarly, weatherinduced variation in the performance of BMPs in reducing mineral $\mathrm{P}$ and TP losses for overgrazing management ranged from -0.46 to $0.31 \mathrm{~kg} \mathrm{ha}^{-1}\left(-0.41\right.$ to $\left.0.28 \mathrm{lb} \mathrm{ac}^{-1}\right)$ and -0.81 to $1.07 \mathrm{~kg} \mathrm{ha}^{-1}$ ( -0.72 to 0.95 $\mathrm{lb} \mathrm{ac}^{-1}$ ), respectively. These results indicate that overgrazing of pasture areas should be avoided in order to see any improvement in the water quality in this watershed.

Filter strips were generally effective in reducing losses of total $\mathrm{N}$, mineral $\mathrm{P}$, and $\mathrm{TP}$ even under uncertain weather conditions. The weather-induced variation in the performance of filter strips greater than $15 \mathrm{~m}$ $(49.2 \mathrm{ft})$ resulted in a reduction of mineral and TP ranging from 0.07 to $0.46 \mathrm{~kg} \mathrm{ha}^{-1}$ ( 0.06 to $0.41 \mathrm{lb} \mathrm{ac}{ }^{-1}$ ) and from 0.09 to 0.81 $\mathrm{kg} \mathrm{ha}^{-1}\left(0.08\right.$ to $\left.0.72 \mathrm{lb} \mathrm{ac}^{-1}\right)$, respectively. The losses of mineral and TP values from the watershed were less than the baseline losses for all weather conditions, indicating that the installation of buffer strips below pasture areas will likely result in water quality improvement. However, for certain BMP scenarios, total $\mathrm{N}$ losses exceeded the baseline values (e.g., see scenarios 96 to 114), indicating that even for $30 \mathrm{~m}(98.4 \mathrm{ft})$ buffer strips weather uncertainty can result in greater losses compared to the baseline values. The performance of $30 \mathrm{~m}$ buffer strip in reducing total $\mathrm{N}$ ranged from -2.33 to 0.63 $\mathrm{kg} \mathrm{ha}^{-1}\left(-2.07\right.$ to $\left.0.56 \mathrm{lb} \mathrm{ac}^{-1}\right)$ for all nutrient management and grazing management due to weather variability.

Often the success of BMPs is evaluated using monitoring data collected during the post-BMP implementation period. It is generally expected that pollutant loads will decrease compared to the pre-implementation period for BMPs to be deemed effective. The results from this study indicated that the effectiveness of BMPs can vary significantly due to weather uncertainty. Extreme weather events observed during postimplementation years can considerably increase or decrease BMP effectiveness compared to the baseline conditions. The effectiveness of conservation practices for a dry period will have a different effectiveness value than the assessment for a wet period, which has greater runoff, soil erosion, and transport (Garbrecht et al. 2006). The dynamic climate can lead to different effectiveness values for the same conservation practices.

\section{Summary and Conclusions}

The objectives of this study were to (1) evaluate the effectiveness of 171 different BMP scenarios in reducing losses of total N, mineral $\mathrm{P}$, and TP from a pasture watershed; (2) quantify interactions among BMPs in reduc- 
ing pollutants of concern; and (3) evaluate impacts of uncertainty in weather conditions on water quality improvement and BMP performance. A SWAT model, along with measured watershed geophysical characteristics in combination with the data for weather conditions of a 25-year simulation period were used to accomplish these objectives. The following conclusions can be drawn from the results obtained in this study.

1. In comparison to the baseline conditions, total $\mathrm{N}$, and TP losses increased with grazing intensity and litter application rates. Fall application resulted in minimum reductions in total $\mathrm{N}$ and TP.

2. Overgrazing of pasture areas resulted in the greatest losses of nutrients for all litter application rates, timings, and buffer management. Overgrazing in pasture areas must be avoided if any improvement in the water quality from other BMPs is to be expected.

3. Buffer strips and litter application timing were the two most important BMPs affecting the losses of total $\mathrm{N}$ and TP from the pasture areas, respectively.

4. A large variability in baseline conditions due to weather uncertainty indicated that even if no changes are made in the watershed, pollutant losses will vary considerably due to inherent variability in weather conditions. Many of the BMP combinations will reduce pollutant losses from the watershed compared to the baseline conditions. However, when weather uncertainty is considered, the 3rd quartile and 90th percentile estimated values exceed the baseline median values, suggesting that the weather variability may mask the reduction in pollutant losses due to BMPs implemented in the watershed. Due to the impacts of weather on water quality, weather variation and uncertainty should be taken into account for assessment of conservation practices in CEAP watersheds.

\section{Acknowledgements}

This study was supported by the USDA Cooperative State Research, Education, and Extension Service under the CEAP (project number 2005-48619-03334). We acknowledge the support by the National Science Foundation TeraGrid program to provide access to the Condor network for model simulations and the technical support of the Purdue University High Performance Computing Center. Comments provided by two anonymous reviewers and an associate editor greatly improved an earlier version of this manuscript.

\section{References}

Abu-Zreig, M., R.P. Rudra, M.N. Lalonde, H.R. Whiteley, and N.K. Kaushik. 2004. Experimental investigation of runoff reduction and sediment removal by vegetated filter strips. Hydrological Processes 18:2029-2037.

Arnold, J.G., R. Srinivasan, R.S. Muttiah, and J.R. Williams. 1998. Large area hydrologic modeling and assessment - Part 1: Model development. Journal of the American Water Resources Association 34(1):73-89.

ASABE (American Society of Agricultural and Biological Engineers). 2005. Manure production and characteristics. ASAE D384.2.

Babiker, I.S., M.A.A. Mohamed, H. Terao, K. Kato, and K. Ohta. 2004. Assessment of groundwater contamination by nitrate leaching from intensive vegetable cultivation using geographical information system. Environment International 29(8):1009-1017.

Bouraoui, F., B. Grizzetti, K. Granlund, S. Rekolainen, and G. Bidoglio. 2004. Impact of climate change on the water cycle and nutrient losses in a Finnish catchment. Climatic Change 66(1-2):109-126.

Burkart, M.R., and J.D. Stoner. 2002. Nitrate in aquifers beneath agricultural systems. Water Science and Technology 45(9):19-28.

CAST (Center for Advanced Spatial Technologies). 2004. 2004 Land Use/Land Cover Data. http://www.cast. uark.edu/cast/geostor/.

Chambers, P.A., R. Meissner, FJ. Wrona, H. Rupp, H. Guhr, J. Seeger, J.M. Culp, and R.B. Brua. 2006. Changes in nutrient loading in an agricultural watershed and its effects on water quality and stream biota. Hydrobiologia 556:399-415.

Chaubey, I., D.R. Edwards, T.C. Daniel, P.A. Moore, and D.J. Nichols. 1995. Effectiveness of vegetative filter strips in controlling losses of surface-applied poultry litter constituents. Transactions of the American Society of Agricultural Engineers 38(6):1687-1692.

Chaubey, I., C.T. Haan, S. Grunwald, and J.M. Salisbury. 1999a. Uncertainty in the model parameters due to spatial variability of rainfall. Journal of Hydrology 220(1-2):48-61.

Chaubey, I., C.T. Haan, J.M. Salisbury, and S. Grunwald. 1999b. Quantifying model output uncertainty due to spatial variability of rainfall. Journal of the American Water Resources Association 35(5):1113-1123.

Condor Team. 2007. Condor® Version 6.8.7 Manual. http:// www.cs.wisc.edu/condor/manual/v6.8.7/index.html.

DeLaune, P.B., P.A. Moore, D.K. Carman, A.N. Sharpley, B.E. Haggard, and T.C. Daniel. 2004. Development of a phosphorus index for pastures fertilized with poultry litter - Factors affecting phosphorus runoff. Journal of Environmental Quality 33(6):2183-2191.

Edwards, D.R., and T.C. Daniel.1992. Potential runoff quality effects of poultry manure slurry applied to fescue plots.
Transactions of the American Society of Agricultural Engineers 35(6):1827-1832.

Edwards, D.R., T.C. Daniel, H.D. Scott, J.F. Murdoch, M.J. Habiger, and H.M. Burks. 1996. Stream quality impacts of best management practices in a northwestern Arkansas basin. Water Resources Bulletin 32(3):499-509.

Garbrecht, J.D. 2008. Multi-year precipitation variations and watershed sediment yield in a CEAP benchmark watershed. Journal of Soil and Water Conservation 63(2):70-76, doi:10.2489/jswc.63.2.70.

Garbrecht, J.D., P.J. Starks, and J.L. Steiner. 2006. The underappreciated climate factor in CEAP. Journal of Soil and Water Conservation 61(4):110A-112A.

Gassman, P.W., M.R. Reyes, C.H. Green, and J.G. Arnold. 2007. The soil and water assessment tool: Historical development, applications, and future research directions. Transactions of the American Society of Agricultural Engineers 50(4):1211-1250.

Gilley, J.E., and L.M. Risse, 2000. Runoff and soil loss as affected by the application of manure. Transactions of the American Society of Agricultural Engineers 43(6):1583-1588.

Gillingham, A.G., and B.S. Thorrold. 2000. A review of New Zealand research measuring phosphorus in runoff from pasture. Journal of Environmental Quality 29(1):88-96.

Gilmour, J.T., M.A. Koehler, M.L. Cabrera, L. Szajdak, and P.A. Moore. 2004. Alum treatment of poultry litter: Decomposition and nitrogen dynamics. Journal of Environmental Quality 33(1):402-405.

Gitau, M.W., I. Chaubey, E. Gbur, J.H. Pennington, and B. Gorham. 2010. Impacts of land-use change and best management practice implementation in a Conservation Effects Assessment Project watershed: Northwest Arkansas. Journal of the Soil and Water Conservation 65(6):353-368, doi:10.2489/jswc.65.6.353.

Gitau, M.W., L. Chiang, M. Sayeed, and I. Chaubey. n.d. Large scale watershed modeling using distributed computing in Condor and SWAT model. Simulation. (In review).

Gitau, M.W., W.J. Gburek, and P.L. Bishop. 2008. Use of the SWAT model to quantify water quality effects of agricultural BMPs at the farm-scale level. Transactions of the American Society of Agricultural and Biological Engineers 51(6):1925-1936.

Gitau, M.W., W.J. Gburek, and A.R. Jarrett. 2005. A tool for estimating best management practice effectiveness for phosphorus pollution control. Journal of Soil and Water Conservation 60(1):1-10.

Gollamudi, A., C.A. Madramootoo, and P. Enright. 2007. Water quality modeling of two agricultural fields in southern Quebec using SWAT. Transactions of the American Society of Agricultural and Biological Engineers 50(6):1973-1980.

Green, C.H., M.D.Tomer, M. Di Luzio, and J.G.Arnold. 2006. Hydrologic evaluation of The Soil and Water Assessment Tool for a large tile-drained watershed in Iowa. Transactions of the American Society of Agricultural and Biological Engineers 49(2):413-422. 
Green, W.R., and B.E. Haggard. 2001. Phosphorus and nitrogen concentrations and loads at Illinois River south of Siloam Springs, Arkansas, 1997-1999. US Geological Survey Water Resource Investigations Report 01-4217.

Harmel, R.D., R.J. Cooper, R.M. Slade, R.L. Haney, and J.G. Arnold. 2006. Cumulative uncertainty in measured streamflow and water quality data for small watersheds. Transactions of the American Society of Agricultural and Biological Engineers 49(3):689-701.

Harmel, R.D., C.G. Rossi, T. Dybala, J. Arnold, K. Potter, J. Wolfe, and D. Hoffman. 2008. Conservation Effects Assessment Project research in the Leon River and Riesel watersheds. Journal of Soil and Water Conservation 63(6):453-460.

Harmel, R.D., and P.K. Smith. 2007. Consideration of measurement uncertainty in the evaluation of goodness of fit in hydrologic and water quality modeling. Journal of Hydrology 337:326-336, doi:10.1016/j.jhydrol.2007.01.043.

Harmel, R.D., H.A. Torbert, B.E. Haggard, R. Haney, and M. Dozier. 2004. Water quality impacts of converting to a poultry litter fertilization strategy. Journal of Environmental Quality 33(6):2229-2242.

Heathman, G.C., D.C. Flanagan, M. Larose, and B.W. Zuercher. 2008. Application of the Soil and Water Assessment Tool and annualized agricultural nonpoint source models in the St. Joseph River watershed. Journal of Soil and Water Conservation 63(6):552-568, doi:10.2489/jswc.63.6.552.

Heathman, G.C., M. Larose, and J.C. Ascough. 2009. Soil and Water Assessment Tool evaluation of soil and land use geographic information system datasets on simulated stream flow. Journal of Soil and Water Conservation 64(1):17-32, doi:10.2489/jswc.64.1.17.

Maski, D., K.R. Mankin, K.A. Janssen, P. Tuppad, and G.M. Pierzynski. 2008. Modeling runoff and sediment yields from combined in-field crop practices using the Soil and Water Assessment Tool. Journal of Soil and Water Conservation 63(4):193-203.

Mayer, P.M., S.K. Reynolds, Jr., T.J., Canfield, and M.D. McCutchen. 2005. Riparian buffer width, vegetative cover, and nitrogen removal effectiveness: A review of current science and regulations. EPA/600/R-05/118.

Merriman, K.R., M.W. Gitau, and I. Chaubey. 2009. Tool for estimating best management practice effectiveness in Arkansas. Applied Engineering in Agriculture 25(2):199-213.

Migliaccio, K.W., and I. Chaubey. 2008. Spatial distributions and stochastic parameter influences on SWAT flow and sediment predictions. Journal of Hydrologic Engineering 13(4):258-269.

Monaghan, R.M., R.J. Paton, L.C. Smith, J.J. Drewry, and R.P. Littlejohn. 2005. The impacts of nitrogen fertilisation and increased stocking rate on pasture yield, soil physical condition and nutrient losses in drainage from a cattle-grazed pasture. New Zealand Journal of Agricultural Research 48(2):227-240.
Moore, P.A., T.C. Daniel, D.R. Edwards, and D.M Miller. 1995. Effect of chemical amendments on ammonia volatilization from poultry litter. Journal of Environmental Quality 24(2):293-300.

Moore, P.A., and D.R. Edwards. 2007. Long-term effects of poultry litter, alum-treated litter, and ammonium nitrate on phosphorus availability in soils. Journal of Environmental Quality 36(1):163-174.

Neitsch S.L., J.G. Arnold, J.R. Kiniry, R. Srinivasan, and J.R. Williams. 2004. Soil and Water Assessment Tool Input/ Output File Documentation, Version 2005. Temple, TX: USDA Agricultural Research Service Blackland Research Center.

Neitsch, S.L., J.G.Arnold, J.R. Kiniry, J.R.Williams, and K.W. King. 2002. Soil and Water Assessment Tool Theoretical Documentation:Version 2000. TWRI Report TR-191, College Station, TX:Texas Water Resources Institute.

Nelson, M.A., L.W. Cash, and G.K. Trost. n.d. Water quality monitoring of Moores Creek above Lincoln Lake 2006 and 2007. (Unpublished)

OWRB (Oklahoma Water Resources Board). 2010. Oklahoma Water Quality Standards. http://www.owrb.ok.gov/util/ rules/pdf_rul/RulesCurrent2010/Ch45.pdf.

Pennington, J.H., M.A. Steele, K.A. Teague, B. Kurz, E. Gbur, J. Popp, G. Rodriguez, I. Chaubey, M. Gitau, and M.A Nelson. 2008. Breaking ground: A cooperative approach to collecting information on conservation practices from an initially uncooperative population. Journal of Soil and Water Conservation 63(6):208A-211A, doi:10.2489/jswc.63.6.208A.

Quansah, J.E., B.A. Engel, and I. Chaubey. 2008. Tillage practices usage in early warning prediction of atrazine pollution. Transactions of the American Society of Agricultural and Biological Engineers 51(4):1311-1321.

Renschler, C.S., and T. Lee. 2005. Spatially distributed assessment of short- and long-term impacts of multiple best management practices in agricultural watersheds. Journal of Soil and Water Conservation 60(6):446-456. SAS Institute. 2007. SAS Version 9.1. Cary, NC: SAS Institute. Schmitt, T.J., M.G. Dosskey, and K.D. Hoagland. 1999. Filter strip performance and processes for different vegetation, widths, and contaminants. Journal of Environmental Quality 28:1479-1489.

Sharpley, A.N., and J.R. Williams. 1990. EPICErosion Productivity Impact Calculator, 1.model documentation. USDA Agricultural Research Service Technical Bulletin 1768.

Shreve,B.R.,P.A.Moore,T.C.Daniel,D.R.Edwards, and D.M Miller. 1995. Reduction of phosphorus in runoff from field-applied poultry litter using chemical amendments. Journal of Environmental Quality 24(1):106-111.

Srivastava, P., D.R. Edwards, T.C. Daniel, P.A. Moore, and T.A. Costello. 1996. Performance of vegetative filter strips with varying pollutant source and filter strip lengths. Transactions of the American Society of Agricultural and Biological Engineers 39(6):2231-2239.
Srivastava, P., K.W. Migliaccio, and J. Simunek. 2007. Landscape models for simulating water quality at point, field, and watershed scales. Transactions of the American Society of Agricultural and Biological Engineers 50(5):1683-1693

SWCS (Soil and Water Conservation Society). 2006 CEAP Final Report. The Soil and Water Conservation Society. http://www.swcs.org/documents/filelibrary/ advocacy_publications/CEAP_Final_Report.pdf.

Syversen, N. 1995. Effect of vegetative filter strips on minimizing agricultural runoff in southern Norway. In Proceedings of the International Workshop, ed. D.K Silkeborg, B. Krenvang, L. Svendsen, E. Sibbesen, 19-31. Neri report no. 178

TeraGrid. 2008. TeraGrid. http://www.teragrid.org.

UAEX (University of Arkansas Cooperative Extension Service). 2006. Forage and Pasture Forage Management Guides. Self-Study Guide 5: Utilization of Forages by Beef Cattle. http://www.aragriculture.org/ forage_pasture/Management_Guides/Forages_Self_ Help_Guide5.htm.

USEPA (US Environmental Protection Agency). 2000. National Water Quality Inventory Report. Washington DC: US Environmental Protection Agency. http:// www.epa.gov/305b/2000report/

USEPA. 2001. Funding Agricultural Best Management Practices with the Clean Water State Revolving Fund (EPA 832-F-01-006).

USEPA. 2003. National Management Measures to Control Nonpoint Source Pollution from Agriculture. (EPA 841-B-03-004).

USGS (US Geological Survey). 2004. USGS Geographic Data Download. http://edc2.usgs.gov/geodata/index.php.

Vendrell, P.F., M.A. Nelson, L.W. Cash, K.F. Steele, R.W. McNew, and J.F. Murdock. 1997. Continuation of the Illinois River water quality monitoring of Moores Creek. Non-Point Source Final Report. Submitted to: Arkansas Soil and Water Conservation Commission. Arkansas Water Resources Center Publication No. MSC-213.

Vendrell, P.F., K.F. Steele, M.A. Nelson, L.W. Cash, and R.W. McNew. 2001. Extended water quality monitoring of the Lincoln Lake watershed. Final Report. Submitted to: Arkansas Soil and Water Conservation Commission. Arkansas Water Resources Center Publication No. MSC-296.

White, K.L., and I. Chaubey. 2005. Sensitivity analysis, calibration, and validations for a multisite and multivariable SWAT model. Journal of the American Water Resources Association 41(5):1077-1089.

Yu, C., W.J. Northcott, and G.F. McIsaac. 2004. Development of an artificial neural network for hydrologic and water quality modeling of agricultural watersheds. Transactions of the American Society of Agricultural and Biological Engineers 47(1):285-290. 